\title{
Penerapan Alat Cuci Tangan Guna Pencegahan Penyebaran Virus COVID-19 di Desa Lagaruda
}

\author{
Muhammad Yahya ${ }^{1}$, Fathahillah ${ }^{2}$, Rissa Megavitry ${ }^{3}$ \\ ${ }^{1}$ Jurusan Pendidikan Teknik Otommotif, Fakultas Teknik, Universitas Negeri Makassar \\ ${ }^{2}$ Jurusan Pendidikan Teknik Elektro, Fakultas Teknik, Universitas Negeri Makassar \\ ${ }^{3}$ Jurusan Pendidikan Kesejahteraan Keluarga, Fakultas Teknik, Universitas Negeri Makassar
}

\begin{abstract}
Partners of the Community Partnership Program (PKM) are people in Laguruda Village where the community in reality does not fully understand and know the procedures for preventing the spread of COVID-19 infection according to WHO standards. The problems are: (1) lack of knowledge on how to prevent the spread of COVID-19 according to WHO recommendations, (2) lack of knowledge on how to wash hands as recommended by WHO, (3) lack of hand washing facilities used to prevent the spread of COVID-19, and (4) not yet available practical hand washing tools to prevent the spread of COVID-19. The external targets are (1) the people of Laguruda village understand how to wash hands properly according to WHO standards and (2) be able to reproduce practical hand washing tools that can be placed anywhere as an effort to prevent the spread of COVID-19.. The methods used are: lectures, demonstrations, discussions, questions and answers, and companion partners. The results achieved are (1) partners have knowledge of how to prevent the spread of COVID-19, (2) partners have adequate hand washing facilities to prevent the spread of COVID-19, and (3) partners have practical hand washing facilities to prevent the spread of COVID-19.
\end{abstract}

Keywords: Corona, Covid-19, Hand Washing, Preventive

\section{PENDAHULUAN}

Corona virus adalah keluarga besar virus yang menyebabkan penyakit mulai dari gejala ringan sampai berat. Ada setidaknya dua jenis corona virus yang diketahui menyebabkan penyakit yang dapat menimbulkan gejala berat seperti Middle East Respiratory Syndrome (MERS) dan Severe Acute Respiratory Syndrome (SARS). Virus corona adalah zoonosis (ditularkan antara hewan dan manusia). Adapun, hewan yang menjadi sumber penularan COVID-19 ini sampai saat ini masih belum diketahui (Ditjen Pencegahan dan Pengendalian Penyakit, 2020).

Tanda dan gejala umum infeksi COVID-19 antara lain gejala gangguan pernapasan akut seperti demam, batuk dan sesak napas. Masa inkubasi COVID-19 berlangsung antara 1 hingga 14 hari dan umumnya dalam waktu 3 hingga 7 hari. Dalam kasus yang parah, umumnya terjadi sesak nafas dan/atau hipoksemia setelah satu minggu. Pada kasus terburuk, bisa secara cepat berkembang menjadi acute respiratory distress syndrome, syok septik, asidosis metabolik yang sulit dikoreksi, kelainan koagulasi dan perdarahan, hingga multiple organ failure. Pada kasus ringan hanya menunjukkan demam ringan, kelelahan ringan, tanpa manifestasi pneumonia ( $\mathrm{Li}$ et al, 2020).

COVID-19 dapat menular dari manusia ke manusia melalui kontak erat dan droplet, tidak melalui udara kecuali jika ada tindakan medis yang memicu terjadinya aerosol dimana dapat memicu terjadinya risiko penularan melalui airborne (Ditjen Pelayanan Kesehatan, 2020). Seseorang juga dapat terinfeksi karena menyentuh permukaan yang terkontaminasi virus ini lalu menyentuh wajahnya (mis., mata, hidung, mulut). Virus COVID-19 dapat bertahan di atas permukaan benda selama beberapa jam tetapi dapat dibunuh dengan disinfektan biasa (Bender, 2020).

Jika terpapar virus dalam jumlah besar dalam satu waktu, dapat menimbulkan penyakit walaupun sistem imun tubuh berfungsi normal. Orang-orang dengan sistem imun lemah seperti orang tua, 
wanita hamil, dan kondisi lainnya, penyakit dapat secara progresif lebih cepat dan lebih parah. Infeksi Coronavirus menimbulkan sistem kekebalan tubuh yang lemah terhadap virus ini lagi sehingga dapat terjadi re-infeksi (Wang et al., 2020).

Individu yang paling berisiko tertular penyakit ini adalah mereka yang kontak erat dengan pasien COVID-19 termasuk yang merawat pasien COVID-19 (Ditjen Pelayanan Kesehatan, 2020). Coronavirus bersifat sensitif terhadap panas dan secara efektif dapat diinaktifkan oleh desinfektan mengandung klorin, pelarut lipid dengan suhu $56^{\circ} \mathrm{C}$ selama 30 menit, eter, alkohol, asam perioksiasetat, detergen non-ionik, formalin, oxidizing agent dan kloroform. Klorheksidin tidak efektif dalam menonaktifkan virus (Wang et al., 2020).

Rekomendasi standar untuk mencegah penyebaran infeksi adalah melalui cuci tangan secara teratur, menerapkan etika batuk dan bersin, menghindari kontak secara langsung dengan ternak dan hewan liar serta menghindari kontak dekat dengan siapa pun yang menunjukkan gejala penyakit pernapasan seperti batuk dan bersin (Ditjen Pencegahan dan Pengendalian Penyakit, 2020). Seseorang dapat melindungi diri dengan mematuhi praktik pencegahan dan pengendalian infeksi, yang mencakup pengendalian lingkungan serta penggunaan Alat Pelindung Diri (APD) yang tepat (yakni tepat dalam pemilihan jenis APD yang sesuai, cara pemakaian, cara pelepasan dan cara pembuangan atau pencucian APD) (Ditjen Pelayanan Kesehatan, 2020).

Masyarakat pada kenyataannya belum sepenuhnya memahami dan mengatahui tata cara untuk mencegah penyebaran infeksi COVID-19 sesuai dengan standar World Health Organization (WHO). Begitupun dengan masyarakat di Desa Lagaruda dimana sebagian besar masyarakat di desa ini masih belum sepenuhnya memahami tentang pentingnya mencuci tangan untuk menghindari infeksi dari virus corona. Hal ini terlihat saat tim PKM melakukan observasi lapangan dimana masih banyak masyarakat yang tidak mencuci tangan sebelum atau setelah menyentuh permukaan benda bahkan masih melakukan kontak fisik dengan orang lain seperti bersalaman ketika bertemu.

Program Kemitraan Masyarakat (PKM) yang telah dilaksanakan bermitra dengan masyarakat di Kantor Desa Laguruda, Kecamatan Sanrobone, Kabupaten Takalar, Jl. Poros Pappanambea.

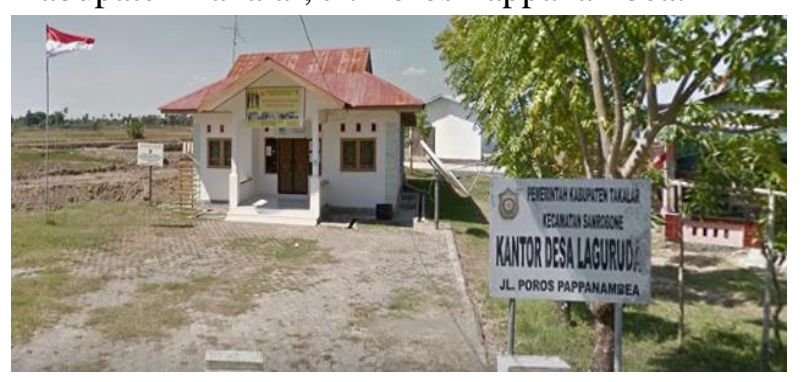

Gambar 1. UKM Mitra PKM



Gambar 1. Spanduk kegiatan PKM

Kondisi UKM mitra sebagai berikut:

a. Kurangnya pengetahuan tentang pencegahan penyebaran COVID-19 sesuai dengan standar WHO

b. Kurangnya pengetahuan tentang cara mencuci tangan yang benar sesuai dengan standar WHO

c. Kurangnya sarana cuci tangan yang digunakan dalam mencegah penyebaran COVID-19

d. Belum tersedianya alat cuci tangan yang praktis untuk mencegah penyebaran COVID-19

Kantor Desa merupakan area publik dimana setiap harinya dikunjungi oleh warga yang berkepentingan untuk mengurus sesuatu maka penting untuk disediakan sarana kebersihan berupa alat cuci tangan yang telah dimodifikasi sehingga mudah untuk digunakan demi mencegah penyebaran COVID-19. Alat cuci tangan yang disediakan dapat diletakkan di halaman depan kantor mengingat tidak tersedianya toilet/kamar mandi umum atau sarana cuci tangan lainnya yang terletak di halaman depan kantor. Mencuci tangan sebelum masuk ke area kantor sangat dianjurkan 
sebab tangan termasuk media penularan COVID19.

\section{METODE YANG DIGUNAKAN}

a. Agar mitra memiliki pengetahuan tentang pencegahan penyebaran COVID-19 sesuai dengan standar WHO, metode yang digunakan adalah ceramah, diskusi, dan tanya jawab.

b. Agar mitra memiliki pengetahuan tentang cara mencuci tangan yang benar sesuai dengan standar WHO, metode yang digunakan adalah ceramah, demonstrasi, diskusi, dan tanya jawab.

c. Agar mitra terampil untuk memproduksi kembali alat cuci tangan yang praktis sebagai bentuk pencegahan penyebaran COVID-19, metode yang digunakan adalah ceramah, diskusi, dan tanya jawab.

\section{PELAKSANAAN DAN HASIL KEGIATAN}

\section{A. Persiapan}

Rangkaian kegiatan pengabdian kepada masyarakat ini diawali dengan persiapan sebaik mungkin agar pelaksanaannya dapat berjalan lancar sesuai yang diharapkan. Untuk itu, persiapan yang dilakukan meliputi tinjauan lapangan, berkunjung ke lokasi untuk mengetahui kondisi masyarakat yang merupakan calon mitra dan kesediaan pemerintah setempat untuk memfasilitasi kegiatan, menentukan waktu pelatihan, perizinan, menyiapkan peralatan-peralatan yang akan digunakan, hingga menentukan jumlah peserta yang akan mengikuti kegiatan.

\section{B. Memberikan gambaran kegiatan}

Pada tahapan ini tim pengabdi memperkenalkan diri kepada para peserta dan menjelaskan secara singkat kegiatan yang akan dilakukan kemudian dilanjutkan dengan meregistrasi peserta yang hadir dalam kegiatan PKM yang dilaksanakan dan penyerahan alat cuci tangan kepada kepala desa Laguruda.



Gambar 3. Penyerahan alat cuci tangan oleh ketua tim pengabdi (kanan) kepada kepala desa Laguruda (kiri)

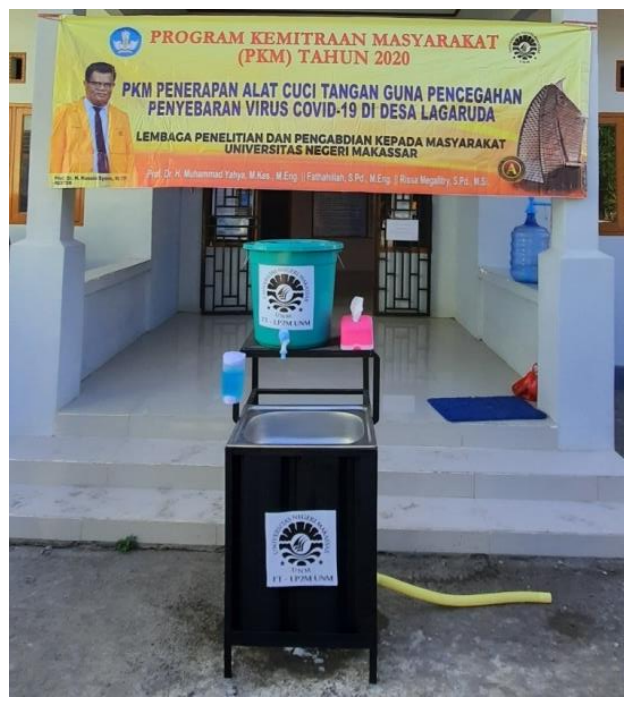

Gambar 4. Alat cuci tangan

\section{Memberikan materi PKM}

Pada tahapan ini, tim pengabdi memberi materi berupa pola penyebaran COVID-19, langkah pencegahan COVID-19 sesuai standar WHO, jenis APD yang dapat digunakan oleh masyarakat sesuai standar WHO, cara menggunakan alat cuci tangan, hingga pentingnya menerapkan panduan pencegahan COVID-19. Tim pengabdi juga menjelaskan mengenai bahan yang digunakan dalam membuat alat cuci tangan dan diharapkan kepala desa dapat memberi penyuluhan lebih lanjut kepada masyarakat desa yang lain sehingga masyarakat desa dapat memproduksi kembali alat cuci tangan sebagai sarana pencegahan COVID-19.

Alat cuci tangan yang telah dimodifikasi berupa ember yang telah diberi kran dibagian bawah sehingga mudah untuk diisi ulang dan bak cuci tangan stainless steel yang ringan sehingga mudah 
untuk dipindahkan atau diletakkan dimana saja. Alat cuci tangan ini juga mudah untuk diproduksi kembali sehingga bisa diproduksi sebagai pemenuhan sarana kebersihan pada rumah tangga lainnya dan mencuci tangan dapat dilakukan di luar rumah/kantor tanpa harus masuk ke dalam area rumah/kantor yang akhirnya dapat meminimalisir penyebaran COVID-19.
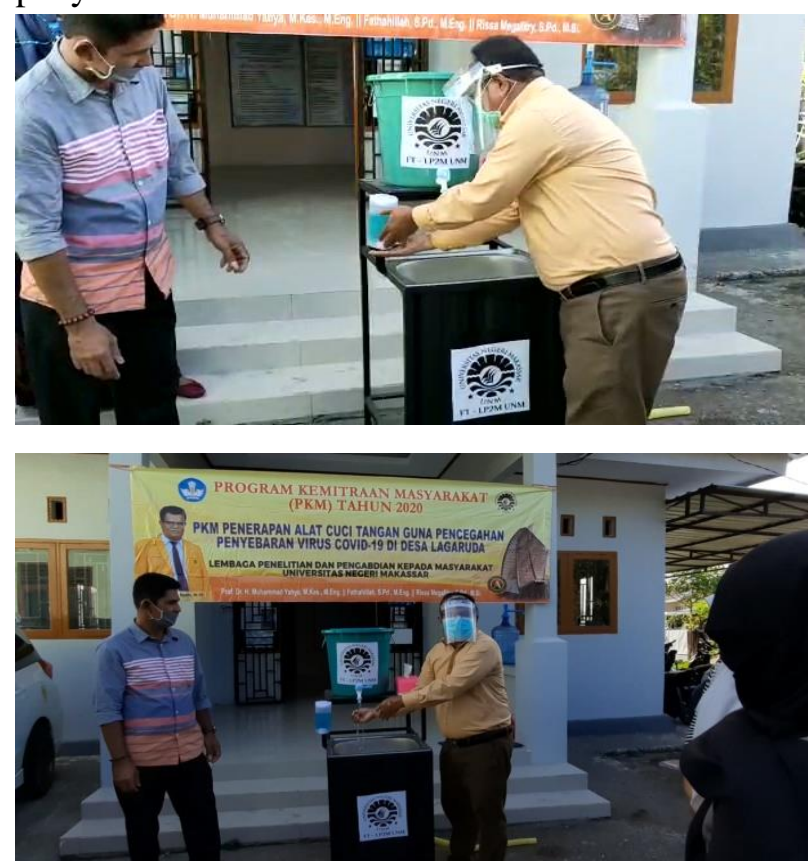

Gambar 5. Menjelaskan cara menggunakan alat cuci tangan dan cara mencuci tangan yang sesuai dengan standar WHO

\section{Sesi diskusi dan tanya jawab dengan mitra $P K M$}

Pada tahapan ini tim pengabdi memberi kesempatan kepada peserta untuk mengajukan pertanyaan. Proses diskusi berlangsung selama ketua tim pengabdian memberikan materi. Selama diskusi berlangsung tidak sedikit peserta yang mengungkapkan bahwa sulit untuk memulai kebiasaan baru yaitu mencuci tangan secara berkala sebab para peserta biasanya melakukan mencuci tangan sebelum dan sesudah makan atau saat merasa tangan mereka kotor.

Para peserta terlihat aktif saat sesi tanya jawab berlangsung dan mulai menjabarkan hal-hal yang mereka kurang pahami seperti apa itu penyakit COVID-19, bagaimana bisa seseorang terinfeksi COVID-19, cara mencegah agar tidak terinfeksi
COVID-19 hingga adakah fenomena infeksi berulang COVID-19.
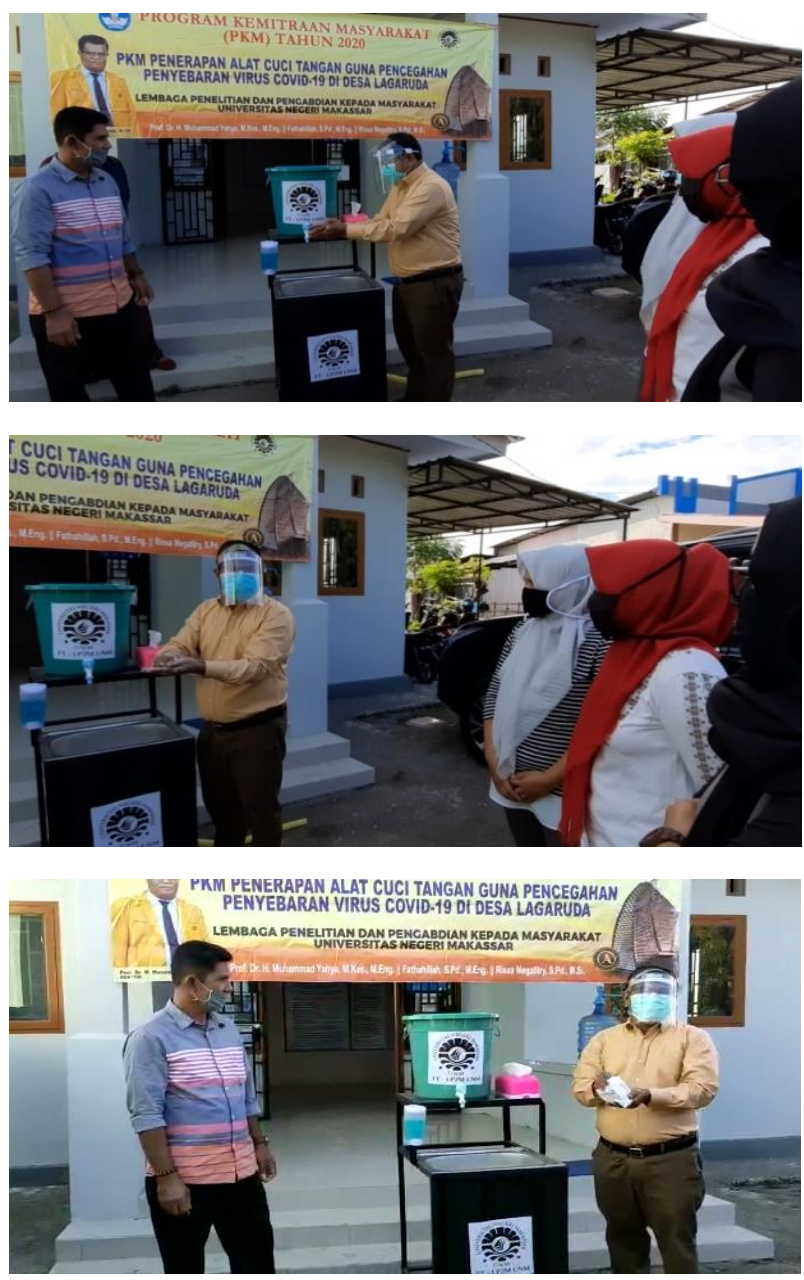

Gambar 6. Diskusi dan tanya jawab dengan peserta pelatihan

\section{KESIMPULAN}

Hasil pelaksanaan kemitraan masyarakat dapat ditarik kesimpulan:

a. Mitra memiliki pengetahuan tentang pencegahan dan pola penyebaran COVID-19 sesuai dengan standar WHO.

b. Mitra memiliki pengetahuan tentang cara mencuci tangan yang benar sesuai dengan standar WHO.

c. Mitra memiliki kemampuan untuk memproduksi kembali alat cuci tangan yang praktis sebagai bentuk pencegahan penyebaran COVID-19. 


\section{UCAPAN TERIMA KASIH}

Ucapan terima kasih disampaikan kepada Direktorat Jendral Pendidikan Tinggi yang telah memberikan hibah. Selanjutnya ucapan terima kasih disampaikan pula kepada Rektor UNM atas arahan dan pembinaanya selama proses kegiatan Pengabdian Masyarakat berlangsung. Demikian pula ucapan terima kasih disampaikan kepada Ketua Lembaga Pengabdian Kepada Masyarakat UNM dan Pemerintah Kabupaten Takalar Provinsi Sulawesi Selatan, yang telah memberi fasilitas, melakukan monitoring, dan mengevaluasi kegiatan PKM hingga selesai.

\section{DAFTAR PUSTAKA}

Bender, Lisa. 2020. Pesan dan Kegiatan Utama Pencegahan dan Pengendalian COVID-19 di Sekolah. Dokumen ini ditulis oleh Lisa Bender (Education UNICEF NYHQ), dengan dukungan teknis dari anggota-anggota UNICEF COVID-19 Secretariat (Carlos Navarro Colorado, Maya Arii \& Hugo Razuri) serta tim UNICEF WASH, C4D dan Child Protection.

Direktorat Jenderal Pencegahan dan Pengendalian Penyakit. 2020. Pedoman Kesiapsiagaan Menghadapi Coronavirus Disease (COVID-19). Jakarta: Kementerian Kesehatan RI

Direktorat Jenderal Pelayanan Kesehatan. 2020. Petunjuk Teknis Alat Pelindung Diri (APD). Jakarta: Kementerian Kesehatan RI

Li, Elcid, Fanggidae V, Teli M. 2020. Guidance for Corona Virus Disease 2019: Prevention, Control, Diagnosis, and Management. China: People's Medical Publishing House

Wang Z, Qiang W, Ke H. 2020. A Handbook of 2019nCoV Pneumonia Control and Prevention. China: Hubei Science and Technologi Press. 